OPEN ACCESS

Edited by:

Juan Pablo Carricart-Ganivet,

National Autonomous University of Mexico, Mexico

Reviewed by: José De Jesús Adolfo Tortolero-Langarica, Technological Institute of Bahía de Banderas, Mexico

Rafael A. Cabral-Tena,

Center for Scientific Research and Higher Education in Ensenada (CICESE), Mexico

*Correspondence: Jürgen Laudien juergen.laudien@awi.de

Specialty section: This article was submitted to

Coral Reef Research,

a section of the journal

Frontiers in Marine Science

Received: 12 August 2021 Accepted: 22 November 2021 Published: 24 December 2021

Citation:

Rossbach S, Rossbach Fl, Häussermann V, Försterra G and Laudien J (2021) In situ Skeletal

Growth Rates of the Solitary Cold-Water Coral Tethocyathus endesa From the Chilean Fjord Region. Front. Mar. Sci. 8:757702. doi: 10.3389/fmars.2021.757702

\section{In situ Skeletal Growth Rates of the Solitary Cold-Water Coral Tethocyathus endesa From the Chilean Fjord Region}

\author{
Susann Rossbach ${ }^{1,2}$, Felix Ivo Rossbach ${ }^{3,4}$, Verena Häussermann ${ }^{4,5}$, Günter Försterra ${ }^{6}$ \\ and Jürgen Laudien ${ }^{1 *}$
}

${ }^{1}$ Alfred-Wegener-Institut Helmholtz-Zentrum für Polar- und Meeresforschung, Bremerhaven, Germany, ${ }^{2}$ Red Sea Development Company, Riyadh, Saudi Arabia, ${ }^{3}$ Faculty of Biology and Chemistry, University of Bremen, Bremen, Germany, ${ }^{4}$ Huinay Foundation, Puerto Montt, Chile, ${ }^{5}$ Departamento de Vinculación con el Medio, Facultad de Economía y Negocios, Universidad San Sebastian, Puerto Montt, Chile, ${ }^{6}$ Facultad de Recursos Naturales, Escuela de Ciencias del Mar, Pontificia Universidad Católica de Valparaíso (PUCV), Valparaíso, Chile

Cold-water corals (CWC) can be found throughout a wide range of latitudes $\left(79^{\circ} \mathrm{N}-\right.$ $\left.78^{\circ} \mathrm{S}\right)$. Since they lack the photosymbiosis known for most of their tropical counterparts, they may thrive below the euphotic zone. Consequently, their growth predominantly depends on the prevalent environmental conditions, such as general food availability, seawater chemistry, currents, and temperature. Most CWC communities live in regions that will face $\mathrm{CaCO}_{3}$ undersaturation by the end of the century and are thus predicted to be threatened by ocean acidification (OA). This scenario is especially true for species inhabiting the Chilean fjord system, where present-day carbonate water chemistry already reaches values predicted for the end of the century. To understand the effect of the prevailing environmental conditions on the biomineralization of the CWC Tethocyathus endesa, a solitary scleractinian widely distributed in the Chilean Comau Fjord, a 12-month in situ experiment was conducted. The in situ skeletal growth of the test corals was assessed at two sites using the buoyant weight method. Sites were chosen to cover the naturally present carbonate chemistry gradient, with $\mathrm{pH}$ levels ranging between $7.90 \pm 0.01$ (mean \pm SD) and $7.70 \pm 0.02$, and an aragonite saturation $\left(\Omega_{\text {arag }}\right.$ ) between $1.47 \pm 0.03$ and $0.98 \pm 0.05$. The findings of this study provide one of the first in situ growth assessments of a solitary CWC species, with a skeletal mass increase of $46 \pm 28 \mathrm{mg}$ per year and individual, at a rate of $0.03 \pm 0.02 \%$ day. They also indicate that, although the local seawater chemistry can be assumed to be unfavorable for calcification, growth rates of $T$. endesa are comparable to other cold-water scleractinians in less corrosive waters (e.g., Lophelia pertusa in the Mediterranean Sea).

Keywords: CWC, calcification, in situ growth, scleractinian, coral 


\section{INTRODUCTION}

More than $50 \%$ of the approximately 5,100 recent coral species are deep and cold-water corals (CWC) (Roberts et al., 2009). These corals are typically heterotrophic, lacking the photosymbionts known for most of their tropical counterparts (Freiwald et al., 2004; Roberts et al., 2009). Thus, most CWC species are found throughout a wide range of latitudes $\left(79^{\circ} \mathrm{N}-78^{\circ} \mathrm{S}\right)$ and at depths below the euphotic zone, with vertical distributions ranging from below $8 \mathrm{~m}$ (Försterra and Häussermann, 2003) down to the abyssal plain at depths down to 4,000 m (Freiwald et al., 2004, 2021; Roberts et al., 2006; Cairns, 2007). In the absence of light-enhanced calcification processes (Falkowski et al., 1984), growth rates of scleractinian CWCs largely depend on other prevailing environmental factors, including food availability, currents, temperature, and in particular seawater carbonate chemistry (Mortensen et al., 1998; Flögel et al., 2014). As a result, their skeletal mass is reported to increase relatively slow (Orejas et al., 2011; Büscher et al., 2017, 2019) in comparison to that of their photosymbiotic tropical conspecifics, with only a few exceptions (see e.g., Desmophyllum dianthus in Jantzen et al., 2013a).

As biomineralization is a key physiological parameter for the fitness of calcifying organisms (Allemand et al., 2011), assessing skeletal growth over time allows addressing various research questions on the response of organisms to biotic and/or abiotic changes in the ecosystem, as well as their resilience to ongoing and persistent environmental changes (Lartaud et al., 2019). While the factors influencing growth and biomineralization rates of tropical, photosymbiotic corals have been intensively studied in recent decades (see e.g., Gattuso et al., 1998; Allemand et al., 2011; Chan and Connolly, 2013), growth rates of their coldwater and deep-sea congeners are less well known. This lack of information is mainly due to the difficulty of accessing their habitats, and consequently, there are few studies on the longterm growth of CWCs, especially in situ. A few studies have so far assessed long-term growth rates of the most common framework forming cold-water scleractinian Lophelia pertusa (Roberts et al., 2009) both, in situ (e.g., Larcom et al., 2014; Büscher et al., 2019) and under different laboratory conditions, e.g., different food supply (Büscher et al., 2017) or different $\mathrm{pCO}_{2}$ levels (Hennige et al., 2014; Büscher et al., 2017). However, knowledge on skeletal growth rates of other CWC species, especially solitary and nonhermatypic corals, is very limited (Jantzen et al., 2013a), although some of these species may constitute a major component of the benthic community and provide three-dimensional structures and habitat for other species (e.g., in the Chilean fjord region; Försterra et al., 2016). Assessing their growth is, therefore, crucial to understand their general ecology, but also their vulnerability to regional and global impacts, and their likely resilience in future scenarios (Jaap, 2000; Rinkevich, 2014).

Ocean acidification (OA), caused by an increase in anthropogenic carbon dioxide $\left(\mathrm{CO}_{2}\right)$ emissions which result in lowered seawater $\mathrm{pH}$ and a decrease in oceans carbonate ion concentrations, consequently diminishes the calcium carbonate $\left(\mathrm{CaCO}_{3}\right)$ saturation state. For this reason, OA is predicted to impair the formation of biogenic $\mathrm{CaCO}_{3}$ in marine calcifiers in general (Orr et al., 2005; Guinotte et al., 2006; Comeau et al., 2009) and in CWCs in specific (e.g., McCulloch et al., 2012a,b; Jantzen et al., 2013b; Hennige et al., 2014; Büscher et al., 2017). $\mathrm{CO}_{2}$ levels in the oceans are predicted to likely reach 900-1,000 $\mu$ atm by the end of the century, exceeding the levels experienced by most marine species over the past 30 million years (Lüthi et al., 2008). In addition, more than $70 \%$ of the global CWC communities live in regions that are predicted to be undersaturated with $\mathrm{CaCO}_{3}$, particularly in the form of aragonite $\left(\Omega_{\text {arag }}\right.$ ) (Maier et al., 2013; Zheng and Cao, 2014). Especially the predicted decline in seawater $\mathrm{pH}$ and the associated problems of $\mathrm{pH}$ homeostasis in organisms are hypothesized to cause changes in calcification rates under predicted future OA conditions (Fabry et al., 2008; Cyronak et al., 2016).

In some regions of the world, for example the Patagonian fjord system, present-day carbonate water chemistry already resembles (and presumably even exceeds) these predictions for the world's oceans by the end of the century (Caldeira and Wickett, 2003; Orr et al., 2005). This environment makes the area an ideal "natural laboratory" for the in situ "future ocean scenario," and several studies have already investigated the response of the local biota to these extreme conditions (e.g., Fillinger and Richter, 2013; Jantzen et al., 2013a,b). In Patagonian fjords, pH levels can be as low as 7.60 (Jantzen et al., 2013b; Försterra et al., 2014), and waters can be undersaturated with aragonite ( $\Omega_{\text {arag }}$ as low as 0.78 ; Jantzen et al., 2013b). With an area of $240,000 \mathrm{~km}^{2}$ and a total length of $1,500 \mathrm{~km}$, the region is also one of the largest connected fjord systems on Earth (Pantoja et al., 2011), highly structured by various channels, islands, fjords, and archipelagos (Figure 1A). Patagonian fjords receive freshwater discharges and organic material originating from rivers and continental run-offs that generate large vertical and horizontal density gradients (Bustamante, 2009). These factors presumably shape the species assemblages in the region, resulting in a structurally and functionally unique ecosystem (Palma and Silva, 2004; Castro et al., 2011). The prevailing environmental conditions are also assumed to be the reason why some of the local CWC species display a surprisingly large vertical distribution range, from shallow depths of about $8 \mathrm{~m}$ down to $1,900 \mathrm{~m}$, and probably even beyond (Cairns et al., 2005; Häussermann and Försterra, 2009; Försterra et al., 2016). Comau Fjord $\left(42^{\circ} 22^{\prime} \mathrm{S}, 72^{\circ} 27^{\prime} \mathrm{W}\right)$, known for its pronounced vertical and horizontal pH gradients (Försterra et al., 2008; Fillinger and Richter, 2013; Jantzen et al., 2013a,b; Rossin et al., 2017), is a typical U-shaped fjord characterized by steep rocky walls with various slopes and overhangs, inhabited by a highly diverse benthic community. One locally common species is the solitary stony coral Tethocyathus endesa (Försterra et al., 2005; Figure 1B). This scleractinian reaches up to $11 \mathrm{~mm}$ in diameter, $8 \mathrm{~mm}$ in height, and is composed of a corallite and a polyp part. It occurs in association with the scleractinians Desmophyllum dianthus and Caryophyllia huinayensis (Cairns et al., 2005; Häussermann and Försterra, 2009; Försterra et al., 2016). However, while D. dianthus and C. huinayensis are mostly found under overhangs and on the steep slopes of the rock faces of these fjords, T. endesa is often found on plateau areas, with their calyx facing toward the water surface and has been reported at 

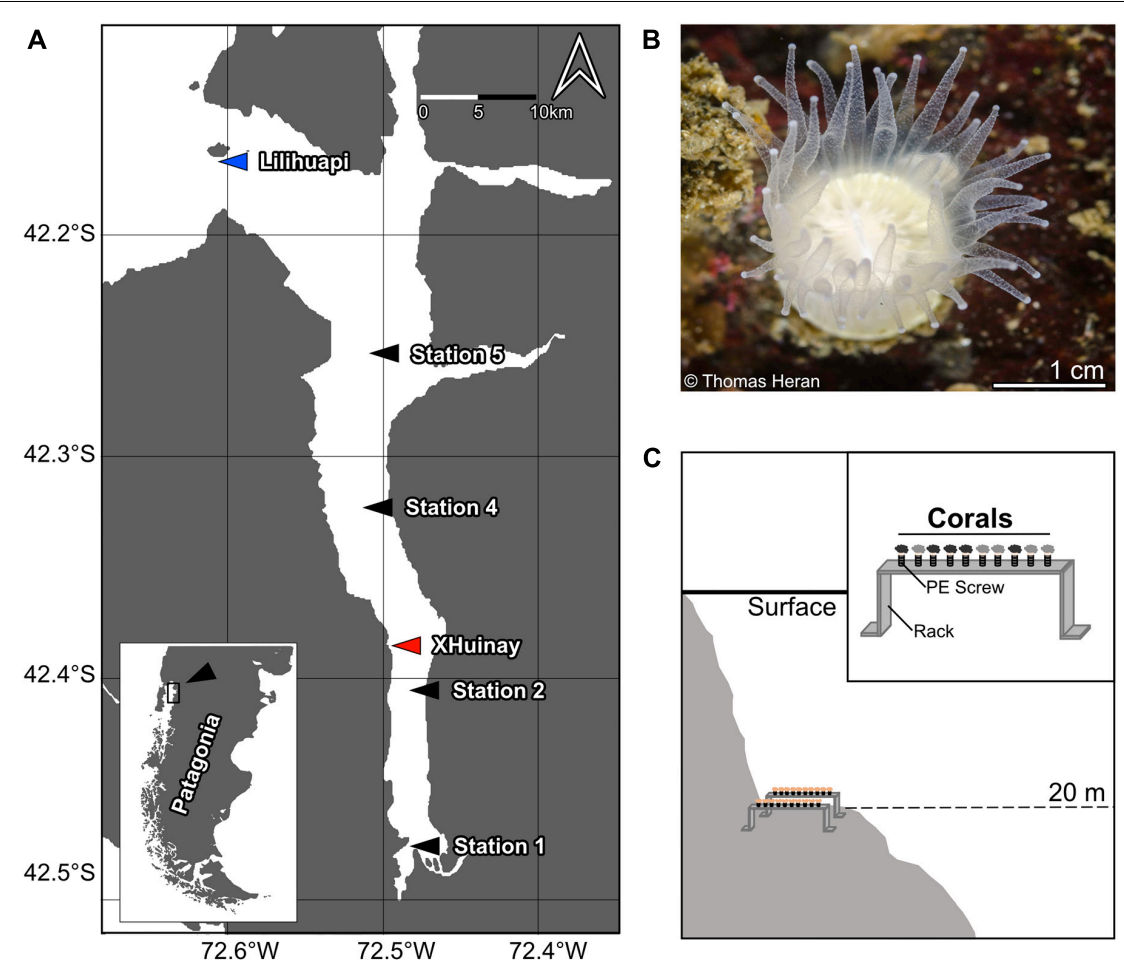

FIGURE 1 | (A) Overview of Patagonian fjord region with Comau Fjord (black rectangle) and 6 CTD stations within the fjord, including the experimental stations XHuinay in the central region of Comau Fjord (red arrow) and Lilihuapi at its mouth (blue arrow). (B) Close-up of a specimen of Tethocyathus endesa (top view). (C) Set-up of coral holder at a depth of $20 \mathrm{~m}$, with coral specimens glued onto polyethylene (PE) screws, which are randomized attached to a mounted rack.

depths of up to $240 \mathrm{~m}$, but also as shallow as $11 \mathrm{~m}$ (Häussermann and Försterra, 2009).

This study provides one of the first in situ assessments on skeletal growth rates of a solitary cold-water scleractinian species, Tethocyathus endesa. It also investigates the naturally present carbonate chemistry gradient in Comau Fjord (from the end to the mouth of the fjord; including low $\mathrm{pH}$ and occasional undersaturation of aragonite) in summer 2014 and summer 2015. The carbonate chemistry of the environment can be assumed to be unfavorable for biomineralization. A subset of experimental corals was also cross-transplanted between two sites (at the center and at the mouth of the fjord) to eliminate the possibility of incorrectly transferring the growth of two subpopulations, each genetically adapted to its own location, to the population occurring in the entire fjord.

\section{MATERIALS AND METHODS}

\section{Characterization of Site}

Comau Fjord is located in the northernmost part of the Chilean fjord region, east of Chiloé island $\left(42^{\circ} 10^{\prime}\right.$ to $42^{\circ} 50^{\prime} \mathrm{N}$ and $72^{\circ} 40^{\prime}$ to $72^{\circ} 60^{\prime} \mathrm{W}$ ) (Figure 1A). It has a total length of $45 \mathrm{~km}$ and reaches a maximum width of $8.5 \mathrm{~km}$ (Häussermann et al., 2012). As a typical fjord in northern Patagonia (Silva, 2008), Comau Fjord is characterized by a strong vertical stratification, as it receives freshwater from precipitation (approx.

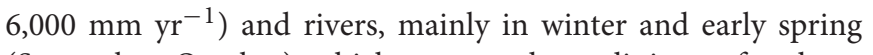
(September-October), which creates a low salinity surface layer $(0.5 \mathrm{~m}$ in summer $-10 \mathrm{~m}$ in winter) with salinities as low as 2 (PSU) (Pantoja et al., 2011; Addamo et al., 2021). Below $18 \mathrm{~m}$ water depth, however, salinity is relatively constant at 32 (PSU) (Addamo et al., 2021), and the intermediate water layer, consisting of Modified Sub-Antarctic Water (MSAAW), compensates the freshwater outflow (Palma and Silva, 2004; Valle-Levinson et al., 2007). Due to the high tidal amplitudes in the region (Schwabe et al., 2006) organisms in the upper water layer (down to approx. 15-20 m) of the fjord are exposed to pronounced fluctuations in salinity and temperature (Häussermann and Försterra, 2009; Jantzen et al., 2013b). Below the pycnocline, monthly mean water temperatures fluctuate seasonally between 8 and $12^{\circ} \mathrm{C}$ (Häussermann et al., 2012; Jantzen et al., 2013b).

The experiment was conducted at two sites, (1) "XHuinay," a site at the western coast of the central fjord area $\left(42^{\circ} 23^{\prime} 25^{\prime \prime}\right.$ $\left.\mathrm{S}, 72^{\circ} 27^{\prime} 32^{\prime \prime} \mathrm{W}\right)$ and at (2) "Lilihuapi” ( $42^{\circ} 09^{\prime} 43^{\prime \prime} \mathrm{S}, 72^{\circ} 35^{\prime} 27^{\prime \prime}$ $\mathrm{W})$, located at the mouth of the fjord (Figure 1A). Sampling sites were chosen based on the prevailing horizontal gradient in seawater carbonate chemistry (e.g., $\mathrm{pH}$, total alkalinity (TA), and $\Omega_{\text {arag }}$ ) between the end and the mouth of the fjord (Jantzen et al., 2013b). On the basis of previous assessments of the environmental conditions at the selected experimental sites (see Jantzen et al., 2013b), it was expected that the water at XHuinay would display a lower $\mathrm{pH}, \mathrm{TA}$, and $\Omega_{\text {arag }}$ than at Lilihuapi. 


\section{Assessment of Physical Parameters and Carbonate Chemistry}

In February 2014, vertical profiles of $\mathrm{pH}$ and salinity were taken at six stations from the end of the fjord to its mouth (i.e., Station 1, Station 2, XHuinay, Station 4, Station 5, and Lilihuapi; Figure 1A), using a CTD multi-probe (SBE 19plusSEACAT Profiler - Conductivity, Temperature, and Pressure with RS 232 Interface, Sea-Bird Electronics Inc.) equipped with a $\mathrm{pH}$ sensor (PHC301, Hach Lange GmbH, Germany). All casts were conducted by hand, and with maximum depths between 83 and $216 \mathrm{~m}$; only the relevant averages for water depths between 17 and $23 \mathrm{~m}$ are reported here, as the experimental corals were located in a water depth of $20 \mathrm{~m}$ (for the full dataset see Laudien et al., 2014).

Additionally, seawater samples were taken between January and February 2015, at a water depth of $20 \mathrm{~m}$ at the two experimental sites $(n=4$ per site), using a 2.5 L Niskin-type water sampler (Hydrobios $\mathrm{GmbH}$, Altenholz, Germany). The $\mathrm{pH}$ was immediately determined manually with a portable $\mathrm{pH}$ probe (PHC301, Hach Lange Company, Düsseldorf, Germany). To further assess the carbonate chemistry at the experimental sites, seawater samples ( $n=4$ per site) were collected on the same day at a depth of $20 \mathrm{~m}$, using SCUBA. For the sampling, a $500 \mathrm{~mL}$ borosilicate bottle (Schott Duran, Germany) was filled with seawater at a depth of $20 \mathrm{~m}$, leaving no air space. Before these seawater samples were analyzed for total alkalinity (TA; i.e., the total concentration of bases and total dissolved solids), they were filtered through glass microfiber filters (Whatman GF/F $25 \mathrm{~mm}$, GE Healthcare Europe GmbH, Freiburg, Germany) to remove particulate organic matter. For each sample, triplicate measurements of TA were performed using potentiometric titration (TitroLine alpha plus+TA05plus, SIAnalytics GmbH, Mainz, Germany and TitriSoft 2.72, Schott Instruments, Mainz, Germany) (Gran, 1952) using certified seawater as reference material (CRM) (Andrew Dickson, Scripps Institution of Oceanography). Further parameters of the carbonate system, i.e., dissolved inorganic carbon (DIC), total alkalinity (TA), partial pressure of carbon dioxide $\left({ }_{p} \mathrm{CO}_{2}\right)$, aqueous carbon dioxide $\left[\mathrm{CO}_{2}(\mathrm{aq})\right]$, as well as aragonite and calcite saturation $\left(\Omega_{\text {arag }}\right.$ and $\Omega_{\text {calc }}$, respectively), were then calculated with the R package Seacarb (Lavigne and Gattuso, 2013) using first and second carbonate system dissociation constants of Lueker et al. (2000), as well as the dissociations of $\mathrm{HF}$ and $\mathrm{HSO}_{4}{ }^{-}$(Dickson and Goyet, 1994), respectively.

In addition, ambient seawater temperature was recorded at the two experimental sites and at a depth of $20 \mathrm{~m}$ throughout the experimental period ( 1 year, from February 2014 till January 2015) using autonomous data loggers (TidbT V2 Temp Logger, Onset Computer Corporation, United States) with a 15-min recording interval.

\section{Cross-Transplantation Experiment}

In February 2014, 20 specimens of T. endesa (Figure 1B) with an average height of $4.1 \pm 0.9 \mathrm{~cm}$ (mean $\pm \mathrm{SD}$ ) were collected by hand in a depth of $20 \mathrm{~m}$ at each of the two experimental sites (total $=40$ ) by SCUBA divers. To minimize the risk of damage and stress during the sampling process, mainly corals growing on a biogenic substrate (primarily on shells of alive limpets Crepidula sp.) were collected together with their substrate. For the transport to the laboratory, specimens were placed in plastic containers, sealed water-tight at the collection site, ensuring no contact with either the brackish surface water layer or air. Experimental specimens were maintained for $48 \mathrm{~h}$ in a 30 liter flow-through aquarium, supplied with unfiltered seawater, continuously pumped up from $25 \mathrm{~m}$ water depth. Corals were then cut from their settling substrate, using a grinding disc attached to a rotary tool (Dremel 4,000, Dremel, The Netherlands), and any additional organic material adhered to the base of coral specimens was removed. Individual corals were then fixed (Super Flex Glue Gel, UHU GmbH und Co KG, Germany) to polyethylene (PE) screws and their initial skeletal mass was determined using the buoyant-weighing method (see below). Finally, corals were brought back to the field and attached (facing upwards) on a customized coral holder installed at a depth of $20 \mathrm{~m}$ at the respective sampling sites (Figure 1C).

Of the original 20 specimens collected per site (i.e., XHuinay and Lilihuapi), ten were returned to the site of origin, serving as a control referred to as " $\mathrm{X}$ " and "L" corals, respectively. The remaining corals were cross-transplanted to the respective other site (Figure 1C) and are now referred to as " $\mathrm{X}$ to L" (for corals transplanted from XHuinay to Lilihuapi) and "L to X" (for those transplanted from Lilihuapi to XHuinay). In this way, 20 T. endesa specimens were installed at each site, with ten control and ten cross-transplanted specimens randomly placed on the previously mounted holding racks. This cross-transplantation of corals between the two experimental sites was conducted to eliminate the possibility of incorrectly transferring the growth of two subpopulations, each genetically adapted to its own location, to the population occurring in the entire fjord.

\section{Skeletal Growth Rate}

The growth rate of $T$. endesa (as mass increase in mg per year and normalized for \% increase per day) was determined using the buoyant-weighing technique (Jokiel, 1978; Davies, 1989), a method widely used for tropical, temperate, and CWCs (e.g., Marubini et al., 2001; Jantzen et al., 2013a; Comeau et al., 2014; Büscher et al., 2019). The buoyant mass of the corals in water ( $\mathrm{m}_{\text {water }}$ in grams) was assessed using an analytical balance (CP 225D-OCE, Sartoris, Germany, precision $0.001 \mathrm{~g}$ ) at the beginning of the experiment in February 2014 and then again at the end in February 2015. The mass of the specimens in air $\left(\mathrm{m}_{\text {air }}\right)$ was then calculated after Jokiel (1978):

$$
m_{\text {air }}=\frac{m_{\text {water }}}{\left(1-\frac{\rho_{\text {water }}}{\rho_{\text {aragonite }}}\right)}
$$

where $\rho_{\text {water }}$ is the seawater density $\left(\mathrm{g} \mathrm{cm}^{-3}\right)$, and $\rho_{\text {aragonite }}$ is the skeleton density of aragonite $\left(\mathrm{g} \mathrm{cm}^{-3}\right)$.

To calculate seawater density during the weighing process (Bialek, 1966), temperature and salinity were assessed using a temperature sensor (WTW ama-digit, WissenschaftlichTechnische Werkstätten GmbH, Germany) and a refractometer (Sinokit Enterprise Limited, Hong Kong). Seawater temperature was kept at $12 \pm 0.5^{\circ} \mathrm{C}$. The difference between the coral mass 
in 2014 and 2015 was taken as the skeletal growth per year (mg $\mathrm{yr}^{-1}$ ). In order to compare the growth rates of T. endesa with those of other CWC and tropical coral species, growth rates (G), were normalized to mass increase per day, as a percentage of the initial mass of the coral $\left(\mathrm{G} \% \mathrm{~d}^{-1}\right)$ using Equation 2:

$$
G=\frac{\left(m_{2}-m_{1}\right)}{m_{1} \times\left(t_{2}-t_{1}\right)} \times 100
$$

where $m_{1}$ is the initial dry mass (in $m g$ ), $m_{2}$ is the dry mass at the end of the experiment, and $t_{2}-t_{1}$ is the duration of the experiment between the final $\left(t_{2}\right)$ and initial $\left(t_{1}\right)$ time in days.

\section{Statistical Analyses}

To compare the skeletal mass increase of $T$. endesa between the four different groups (i.e., "X," "L," "X to L," and "L to X") and to test for significant differences $(p \leq 0.05)$ between the in situ skeletal growth at the two experimental sites (i.e., XHuinay and Lilihuapi), pairwise Wilcoxon tests and Kruskal-Wallis tests were used. All statistical analyses were performed using R (Foundation for Statistical Computing, Austria, Version 3.5.3).

\section{RESULTS}

\section{Physical Parameters and Carbonate Chemistry}

In 2014, the seawater $\mathrm{pH}$ (averaged for a depth between 17 and $23 \mathrm{~m}$; for the full dataset, see Laudien et al., 2014), assessed at the six sampling sites (i.e., Station 1, Station 2, XHuinay, Station 4, Station 5, and Lilihuapi; Figures 1A, 2A) highlighted the pronounced horizontal gradient from the end of the fjord toward its mouth. The seawater $\mathrm{pH}$ ranged from $7.57 \pm 0.01$ (Station 1 ; mean $\pm \mathrm{SD}$ ) via $7.63 \pm 0.02$ at XHuinay, to an average of $7.90 \pm 0.01$ at Lilihuapi (Figure 2A and Table 1). The additional manual $\mathrm{pH}$ measurements from 2015, conducted only at the experimental sites (i.e., XHuinay and Lilihuapi), at a depth of $20 \mathrm{~m}$ further underline these particularly low seawater $\mathrm{pH}$ values in the region, with $7.70 \pm 0.02$ at XHuinay and $7.90 \pm 0.01$ at Lilihuapi (Table 1; for full dataset see Diercks et al., 2015a,b). Low TA also characterized the seawater at the two sites, with $2,234 \pm 36 \mu \mathrm{mol} \mathrm{l}^{-1}$ at XHuinay, and 2,216 $\pm 19 \mu \mathrm{mol} \mathrm{l}^{-1}$ at Lilihuapi, resulting in an undersaturation $\left(\Omega_{\text {arag }} 0.98 \pm 0.05\right)$ at XHuinay and a low aragonite saturation $\left(\Omega_{\text {arag }} 1.47 \pm 0.03\right)$ at Lilihuapi (Table 1).

Between February 2014 and January 2015, the mean water temperature at the central fjord at XHuinay was $11.5 \pm 0.5^{\circ} \mathrm{C}$, with monthly variations ranging from $10.55 \pm 0.15^{\circ} \mathrm{C}$ in August 2014 (austral winter) to $12.64 \pm 0.89^{\circ} \mathrm{C}$ in March 2014 (austral summer; Figure 2B and Table 1). The highest water temperature of $15.30^{\circ} \mathrm{C}$ was recorded in December 2014, and the lowest of $9.93^{\circ} \mathrm{C}$ was logged in August 2014. Maximum monthly temperature fluctuations of $\Delta 0.89^{\circ} \mathrm{C}$ and $\Delta 0.77^{\circ} \mathrm{C}$ were recorded in March 2014 and December 2014, respectively. At Lilihuapi, the average annual water temperature was $12.9 \pm 0.9^{\circ} \mathrm{C}$, with the water coldest in August $2014\left(10.41 \pm 0.17^{\circ} \mathrm{C}\right)$ and warmest in February $2014\left(12.85 \pm 0.93^{\circ} \mathrm{C}\right.$; Figure 2B and Table 1). The highest water temperature at this site $\left(15.53^{\circ} \mathrm{C}\right)$ was recorded in February 2014, the lowest in August $2014\left(9.46^{\circ} \mathrm{C}\right)$. The largest monthly temperature fluctuations of $\Delta 0.93^{\circ} \mathrm{C}$ were recorded in February and December 2014 at Lilihuapi.

The salinity-driven pycnocline was very pronounced at XHuinay (Figure 2C; for full dataset see Laudien et al., 2014), extending between 5 and $12 \mathrm{~m}$ water depth, with an average salinity of $25.3 \pm 0.07$ in surface waters $(<5 \mathrm{~m})$ and $32.5 \pm 0.2$ in waters below $12 \mathrm{~m}$. At Lilihuapi, the pycnocline was less pronounced but also present between 5 and approximately $12 \mathrm{~m}$ water depth, with a salinity of $30.1 \pm 0.4$ in shallower waters $(<5 \mathrm{~m})$ and $32.5 \pm 0.1$ below $12 \mathrm{~m}$ (Figure 2C). Consequently, the salinity at $20 \mathrm{~m}$, the respective depth at which the T. endesa specimens were mounted on the coral holders, was similar at the two experimental sites, with $32.7 \pm 0.1$ at XHuinay and $32.6 \pm 0.1$ at Lilihuapi (Table 1).

\section{Skeletal Growth}

In January 2015, all experimental specimens were alive and none showed any obvious visible sign of degradation (e.g., tissue damage/loss or bioerosion). Overall, there was no significant difference between the skeletal growth rates of $T$. endesa specimens at the two experimental sites XHuinay and Lilihuapi (Figure 3 and Supplementary Table 1). Neither between specimens of the control groups (i.e., "X" and "L"), which remained at their site of origin, nor between the crosstransplanted individuals (i.e., "X to L" and "L to X"). Therefore, growth rates of $T$. endesa from Comau Fjord were averaged for all specimens, indicating an increase of skeletal mass of $46 \pm 28$ milligrams per year and individaul, or $0.03 \pm 0.02 \%$ per day. Out of the 40 corals in the experimental setup, only two transplanted specimens showed a decrease or stagnation in mass over the experimental period, one from the group "X to L" with an average decrease of $-0.02 \%$ per day, and one specimen of the group " $L$ to $\mathrm{X}$," where the mass remained almost identical $\left(<-0.002 \% \mathrm{~d}^{-1}\right)$ between 2014 and 2015.

\section{DISCUSSION}

\section{Physical Parameters and Carbonate Chemistry of Comau Fjord}

Patagonian fjords are known for their low seawater $\mathrm{pH}$, which is assumed to result from the high geological activity and seeps of volcanic origin in the region (Pantoja et al., 2011; Jantzen et al., 2013b; Muñoz et al., 2014). The emerging gradient from the mouth to the end of these fjords is also reflected in the carbonate chemistry of the seawater in Comau Fjord, characterized by an overall comparatively low $\mathrm{pH}$ and a horizontal $\mathrm{pH}$ gradient with the lowest values at the end of the fjord (Station 1 with $7.57 \pm 0.01$ ). In the center (Station XHuinay), a $\mathrm{pH}$ of $7.70 \pm 0.02$ was measured, and the highest $\mathrm{pH}$ of $7.90 \pm 0.01$ at its mouth (Station Lilihuapi). Here, the influence of the Pacific Ocean increases (Pickard, 1971), and the fjord water mixes with that of the Gulf of Ancud. Combined with the low total alkalinity (TA) of the fjord water, the carbon equilibrium shifts toward $\mathrm{CO}_{2}$, leading to a reduction in the overall aragonite 

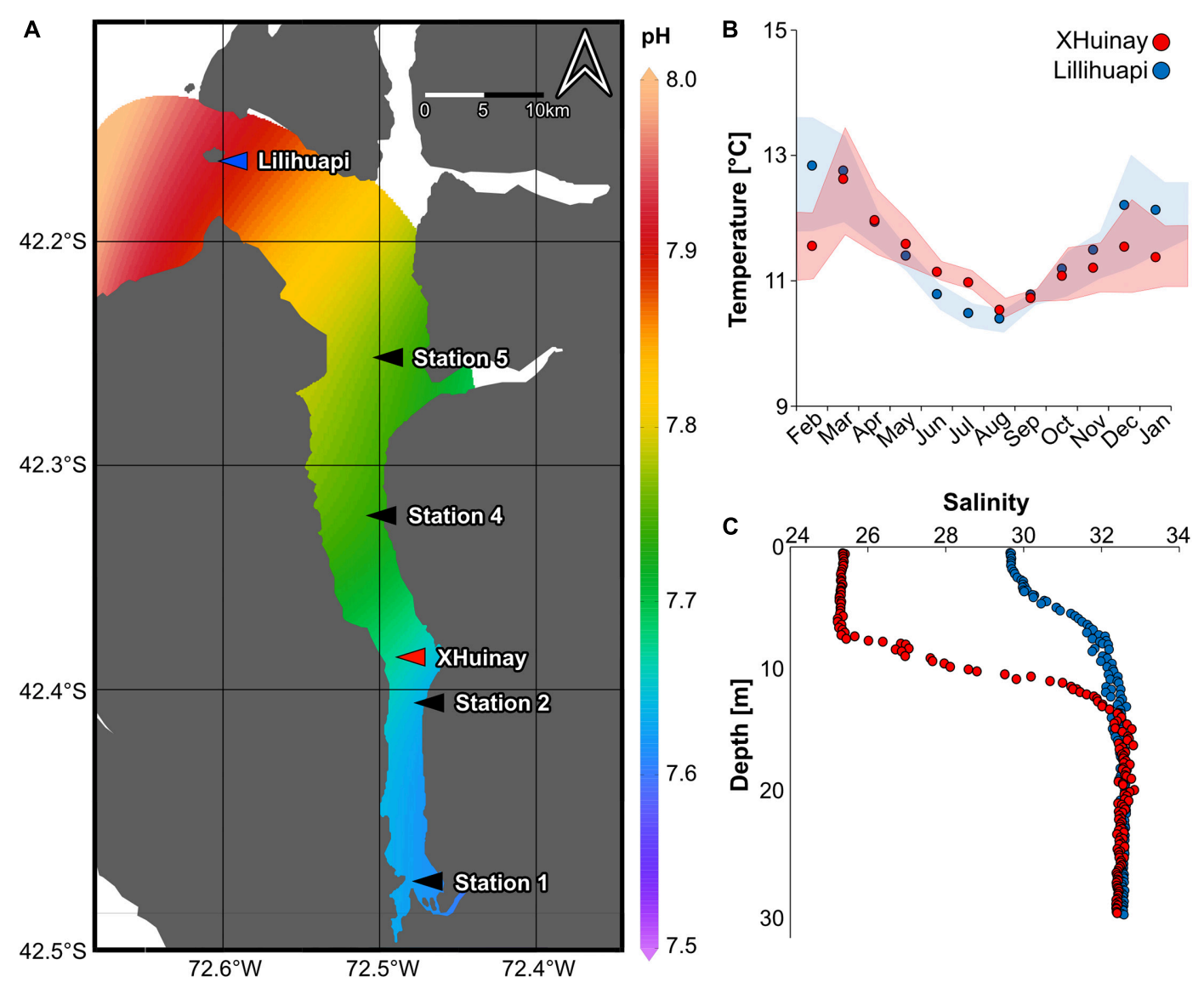

FIGURE 2 | Environmental parameters of Comau Fjord (2014-2015). (A) Average pH (17-23 m water depth; February 2014) throughout the fjord (end-mouth), resolved from six CTD casts at different stations within the fjord, including the two experimental stations XHuinay (red) and Lilihuapi (blue). (B) Monthly average water temperature (January 2014-February 2015) at a depth of $20 \mathrm{~m}$ at the two experimental sites. Dots refer to the monthly means, the shaded areas to the variation between minimum and maximum temperature during the respective month. (C) Salinity at the two experimental sites from the surface to $30 \mathrm{~m}$ depth (February 2014); XHuinay = red and Lilihuapi = blue.

TABLE 1 | Physical parameters and carbonate chemistry.

\begin{tabular}{|c|c|c|c|c|c|c|c|c|c|c|c|}
\hline Station & Year & Depth [m] & Temp $\left[{ }^{\circ} \mathbf{C}\right]$ & Sal (PSU) & $\mathrm{pH}$ & $\mathrm{TA}\left[\mu \mathrm{mol} \mathrm{I}^{-1}\right]$ & $\mathrm{DIC}\left[\mu \mathrm{mol} \mathrm{I}^{-1}\right]$ & $\mathrm{pCO}_{2}[\mu \mathrm{atm}]$ & $\mathrm{CO}_{2(\mathrm{aq})}\left[\mu \mathrm{mol} \mathrm{I}^{-1}\right]$ & $\mathbf{\Omega}_{\mathrm{arag}}$ & $\Omega_{\text {calc }}$ \\
\hline \multirow[t]{2}{*}{ XHuinay } & 2014 & $17-23$ & \multirow{2}{*}{$11.5 \pm 0.5$} & $32.5 \pm 0.1$ & $7.63 \pm 0.02$ & $N A$ & $N A$ & $N A$ & $N A$ & $N A$ & $N A$ \\
\hline & 2015 & 20 & & $32.7 \pm 0.1$ & $7.70 \pm 0.02$ & $2,234 \pm 36$ & $2,182 \pm 34$ & $955 \pm 42$ & $941 \pm 42$ & $0.98 \pm 0.05$ & $1.54 \pm 0.08$ \\
\hline \multirow[t]{2}{*}{ Lilihuapi } & 2014 & $17-23$ & \multirow{2}{*}{$12.9 \pm 0.9$} & $32.6 \pm 0.1$ & $7.90 \pm 0.01$ & $N A$ & $N A$ & $N A$ & $N A$ & $N A$ & $N A$ \\
\hline & 2015 & 20 & & $32.6 \pm 0.1$ & $7.90 \pm 0.01$ & $2,216 \pm 19$ & $2,098 \pm 21$ & $577 \pm 21$ & $568 \pm 21$ & $1.47 \pm 0.03$ & $2.31 \pm 0.06$ \\
\hline
\end{tabular}

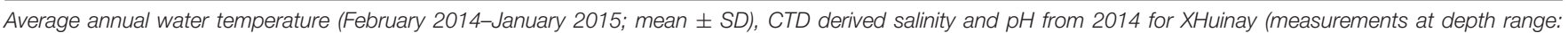

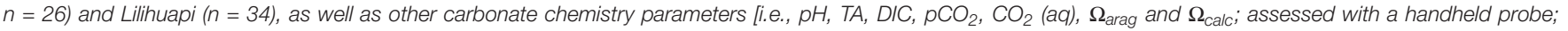
$n=4]$ in 2015.

saturation state (Kleypas et al., 1999; Zeebe and Wolf-Gladrow, 2001), with occasional undersaturation of the waters, for example at XHuinay $\left(\Omega_{\text {arag }} 0.98 \pm 0.05\right)$. Seawater that is undersaturated $(<1)$ in aragonite is assumed to be corrosive and thus inhibits calcification as it may promote the dissolution of unprotected aragonite structures (Feely et al., 1988, 2008). However, it has also been suggested that the increased availability of bicarbonate, due to an enhanced $\mathrm{pCO}_{2}$ may facilitate calcification, although it simultaneously decreases the $\Omega_{\text {arag }}$ (Marubini et al., 2008; Jury et al., 2010). Comparing the seawater chemistry at the two experimental sites in 2014 and 2015 with the previous reports from 2010 and 2011 (Jantzen et al., 2013b) also shows that it is subjected to temporal variations. While the seawater $\mathrm{pH}$ and salinity at the experimental sites remained stable over these five years, the TA in 2010/11 at both sites were slightly lower than the ones measured in the present study. Salinity mainly influences TA of the ocean and thus the corresponding $\mathrm{Cl}^{-}$and $\mathrm{Na}^{+}$concentrations, as well as biogeochemical processes such as the production of particulate organic matter by microalgae and the precipitation of calcium carbonate (Wolf-Gladrow et al., 


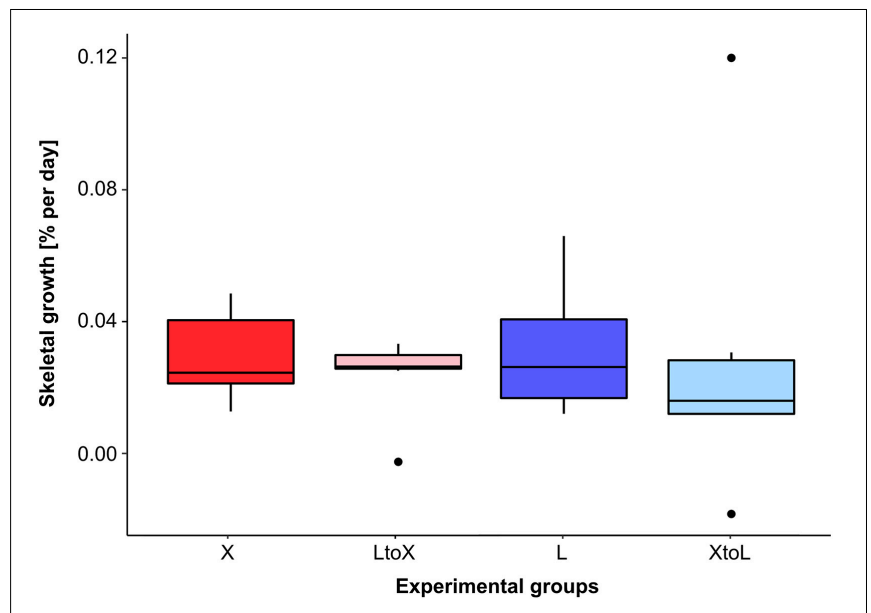

FIGURE 3 | Skeletal growth rates [\% $\mathrm{d}^{-1}$ ] of $T$. endesa specimens from four experimental groups. Growth rates of control corals from the central region of Comau Fjord at XHuinay $(X$; red) and of corals transplanted from Lilihuapi to XHuinay ( $L$ to $X$, light red), as well as the control corals at the mouth of the fjord at Lilihuapi ( $L$, blue) and of corals transplanted from XHuinay to Lilihuapi (X to L; light blue).

2007). Since salinity did not change during the respective years, the amount of organic matter and the precipitation of calcium carbonate may be the cause of these TA differences. This observation may also be an indication of the dynamics of the abiotic environmental conditions in the region.

Given this, and the fact that the present study only includes the assessment at two time points (i.e., in February 2014 and February 2015), it remains unclear whether the differences in carbonate chemistry at the two experimental sites (i.e., XHuinay and Lilihuapi) persist throughout the year and/or if they are subject to fluctuations. Since the assessed skeletal growth rates of $T$. endesa at the two experimental sites (for both, crosstransplanted and control corals) were not significantly different, we report below on the general in situ skeletal growth rates of T. endesa in Comau Fjord.

\section{In situ Skeletal Growth Rates of T. endesa}

On average, the skeletal mass of $T$. endesa specimens increased by $46 \pm 28$ milligrams per year, corresponding to $0.03 \pm 0.02 \%$ per day. These growth rates are comparable to those reported for other CWC species, such as L. pertusa from the North-Atlantic (0.01 $\pm 0.01 \%$ per day; Büscher et al., 2019), or Dendrophyllia cornigera (0.04 $\pm 0.02 \%$ per day; Orejas et al., 2011).

However, the growth of CWC species can be influenced by various environmental factors, such as temperature (Grigg, 1974; Matsumoto, 2007; Silverman et al., 2007), current speed (Purser et al., 2010), prey abundance (Silverman et al., 2007; Purser et al., 2010; Naumann et al., 2011), and the aragonite saturation status (Gattuso et al., 1998; Silverman et al., 2007; Jury et al., 2010; Form and Riebesell, 2012; Büscher et al., 2019). The relatively harsh environmental conditions of Comau Fjord (with particularly low $\mathrm{pH}$ and $\Omega_{\text {arag }}$ ) may thus challenge the calcium precipitation in $T$. endesa, resulting in reduced growth rates than would be the case under more calcification-favorable conditions. The variety of growth responses of marine calcifiers to a low seawater $\mathrm{pH}$ may thus reflect the actual range and plasticity of acclimatization potentials of some species to maintain their skeletal growth rates, over a range of seawater $\Omega_{\text {arag }}$ (McCulloch et al., 2012a,b; Cohen et al., 2017). For instance, some solitary and temperate coral species, such as Caryophyllia smithii (McCulloch et al., 2012a) and D. dianthus (Wall et al., 2016), are suspected being capable of an active physiological adaption to the low $\mathrm{pH}$ of ambient seawater by regulating their internal $\mathrm{pH}$ through an increased $\mathrm{Ca}^{2+}$-ATPase activity (McCulloch et al., 2012a,b). Consequently, these species are capable to regulate the $\mathrm{pH}$ in their tissues up to 0.78 units above the $\mathrm{pH}$ of the surrounding seawater (McCulloch et al., 2012a,b). As T. endesa shows skeletal growth rates comparable to those of other CWC species from less corrosive seas (e.g., Mediterranean Sea), this species may also be capable of such an up-regulation of the internal $\mathrm{pH}$, when seawater $\Omega_{\text {arag }}$ is below 1 as it was the case in January 2015 in XHuinay (Table 1). However, the physiological responses of this species to its environment are still unknown and need future investigation. Such a $\mathrm{pH}$ elevation would also be accompanied by an increased energetic expenditure, leading to a reduction of energy for other physiologically important processes. A 0.1 unit decrease in seawater $\mathrm{pH}$ may result in a $10 \%$ increase in energy budget (McCulloch et al., 2012b). The finding that the majority of the corals in this experiment (95\%) sustain net positive calcification rates under the prevalent, harsh environmental conditions thus suggests that such an potentially increased energy demand would be met by the relatively large zooplankton abundances and amounts of particulate and dissolved organic matter that the local fjord systems receive, either from marine or terrestrial primary production (Montero et al., 2011; Sánchez et al., 2011), or anthropogenic sources, such as detritus from terrestrial plants, urban, and aquaculture waste (Rojas and Silva, 2005). However, further research, including extension of the experiments reported here (e.g., over several years), but also on the physiological mechanisms involved, is needed to understand how $T$. endesa can sustain its growth rates and calcification over long term under the harsh local environmental conditions.

\section{Comparison to Other Cold-Water Corals and Photosymbiotic Coral Species}

Skeletal growth of tropical and photosymbiotic scleractinians has been extensively studied in the past, both in situ and under a variety of experimental conditions in the laboratory, for example under different light intensities (e.g., Rodolfo-Metalpa et al., 2008; Schutter et al., 2012), feeding regimes (e.g., Houlbrèque et al., 2003; Houlbreİque et al., 2004), water temperatures (e.g., Carricart-Ganivet, 2004; Rodolfo-Metalpa et al., 2008), and nutrient availabilities (e.g., Ferrier-Pagès et al., 2000; Tanaka et al., 2007). However, data on growth rates of cold-water scleractinians are scarce, mainly because CWC ecosystems have only recently gained attention (Freiwald et al., 2004). This is particularly true for CWC that are part of benthic communities in remote areas, such as the solitary coral species $T$. endesa from the Chilean 
fjord region. Like other benthic species in this region (e.g., other CWC species such as C. huinayensis), T. endesa was only recently described (Cairns et al., 2005) and thus information on its ecology and physiology is still extremely scarce. The general lack of data for CWC is also due to the fact that there are only a few locations worldwide where these organisms are relatively easy to access, such as the Patagonian fjord system and some Norwegian fjords. As a consequence, only few studies have assessed longterm growth rates of CWCs (e.g., Brooke and Young, 2009; Orejas et al., 2011; Larcom et al., 2014; Büscher et al., 2019). However, these mainly focused on the most common framework forming cold-water scleractinian (Roberts et al., 2009) L. pertusa, and the solitary CWC species D. dianthus (Hassenrück et al., 2013; Jantzen et al., 2013a; Martínez-Dios et al., 2020), and their growth rates were assessed both, under different laboratory conditions, e.g., different food supply (Büscher et al., 2017) or different $\mathrm{pCO}_{2}$ levels (Hennige et al., 2014; Büscher et al., 2017), and in situ (e.g., Brooke and Young, 2009; Larcom et al., 2014; Büscher et al., 2019). These studies also used a range of different techniques, such as geochemical analysis of skeletal isotopes (Mikkelsen et al., 1982; Mortensen et al., 1998), visual growth banding patterns (Brooke and Young, 2009), estimates from in situ video recordings (Larcom et al., 2014), or buoyant weighing (Orejas et al., 2011; Jantzen et al., 2013a; Büscher et al., 2019). The results of this study are therefore not only the first scientific report on skeletal growth rates of the CWC T. endesa, but also one of the first in situ assessments of a solitary CWC species in general.

The comparison of skeletal growth rates of $T$. endesa from this study to previous reports on other heterotrophic coldwater, or temperate coral species (Table 2) reveals that growth rates can vary considerably depending on species, location, and experimental approach (i.e., in situ or laboratory; long-term or short-term measurements). This highlights the importance of further studies on CWC species to gain a better understanding of their ecology, physiology, and response to a changing ocean. For instance, the 1-year in situ skeletal growth of $T$. endesa $\left(0.03 \pm 0.02 \% \mathrm{~d}^{-1}\right)$ was comparable to rates previously reported for L. pertusa from the North Atlantic (with a long-term in situ skeletal growth rate of $0.01 \pm 0.01 \%$ per day; Büscher et al., 2019), and the Mediterranean (long-term rate of $0.02 \pm 0.01 \%$ per day assessed in laboratory experiment; Orejas et al., 2011), as well as from Dendrophyllia cornigera (long-term growth rate of $0.04 \pm 0.02 \%$ per day assessed in the laboratory; Orejas et al., 2011). However, the short-term (2 weeks) skeletal growth rates of $D$. dianthus, also from Comau Fjord, were between three times (when assessed in situ) and eight times (when assessed in a laboratory experiment) higher (Jantzen et al., 2013a) than those of T. endesa. However, it is noteworthy that the reported short-term growth rates of $D$. dianthus of $0.25 \pm 0.18 \%$ per day (Jantzen et al., 2013a) is also one of the rare occasions when a heterotrophic CWC species exhibits growth rates comparable to photosymbiotic, tropical conspecifics, such as Pocillopora damicornis $\left(0.2-0.3 \% \mathrm{~d}^{-1}\right.$; Piniak and Brown, $2008)$ or Stylophora pistillata $\left(0.35 \pm 0.07 \% \mathrm{~d}^{-1}\right.$; Ferrier-Pagès et al., 2000). These comparatively high growth rates, reported by Jantzen et al. (2013a) might also be biased by seasonal effects, as it has been shown that $D$. dianthus increases its feeding response linearly with prey abundance (Höfer et al., 2018). As the short-term growth rates of $D$. dianthus were assessed during austral summer, the potential oversupply of food during this season may have led to a temporary peak in skeletal growth, leading to an overestimation of the overall growth rates of this species.

When comparing the skeletal growth rates of different CWC species obtained in different studies, the limitations of the respective experimental approaches must also be taken into account. While in situ measurements are limited in determining all potential influencing factors responsible for coral metabolism and growth rates (e.g., food availability, as well as daily or seasonal variations of various water parameters), it has been shown that in laboratory experiments, the quality of the cultivation of the CWCs may have a significant impact (Jantzen et al., 2013a; Lartaud et al., 2014). Direct comparison of coral growth rates between different studies should thus be considered with some caution, as variations in the cultivation setups, divergent measurement methods, and time frames, as well as other factors (e.g., temperature, feeding regime, or ambient carbonate chemistry), may influence growth.

\section{Other Considerations}

Although we did not observe any obvious traces of bioeroding organisms (e.g., boring sponges, polychaetes or gastropods) on the experimental specimens, it cannot be excluded that the latter

TABLE 2 | Comparison of skeletal growth (\% increase per day \pm SD) between different cold-water, temperate, and tropical/photosymbiotic coral species.

\begin{tabular}{|c|c|c|c|c|c|c|c|}
\hline Species & Location & $\%$ increase $\mathrm{d}^{-1}$ & Time & Exp. Setup & Temp $\left({ }^{\circ} \mathrm{C}\right)$ & Method & References \\
\hline Tethocyathus endesa & Comau Fjord, Chile & $0.03 \pm 0.02$ & 1 year & In situ & $12^{\circ} \mathrm{C}$ & Buoyant weight & This study \\
\hline Desmophyllum dianthus & Comau Fjord, Chile & $0.09 \pm 0.08$ & 2 weeks & Laboratory & $12^{\circ} \mathrm{C}$ & Buoyant weight & Jantzen et al., 2013b \\
\hline Desmophyllum dianthus & Comau Fjord, Chile & $0.25 \pm 0.18$ & 2 weeks & In situ & $12^{\circ} \mathrm{C}$ & Buoyant weight & Jantzen et al., 2013b \\
\hline Lophelia pertusa & North Atlantic & $0.01 \pm 0.01$ & 1 year & In situ & $8^{\circ} \mathrm{C}$ & Buoyant weight & Büscher et al., 2019 \\
\hline Lophelia pertusa & Mediterranean Sea & $0.02 \pm 0.01$ & 1 year & Laboratory & $12^{\circ} \mathrm{C}$ & Buoyant weight & Orejas et al., 2011 \\
\hline Dendrophyllia cornigera & Mediterranean Sea & $0.04 \pm 0.02$ & 8 months & Laboratory & $12^{\circ} \mathrm{C}$ & Buoyant weight & Orejas et al., 2011 \\
\hline Desmophyllum dianthus & Mediterranean Sea & $0.06 \pm 0.03$ & 8 months & Laboratory & $12^{\circ} \mathrm{C}$ & Buoyant weight & Orejas et al., 2011 \\
\hline Madrepora oculata & Mediterranean Sea & $0.11 \pm 0.04$ & 2 years & Laboratory & $12^{\circ} \mathrm{C}$ & Buoyant weight & Orejas et al., 2011 \\
\hline Stylophora pistillata & Red Sea & $0.35 \pm 0.07$ & 18 weeks & Laboratory & $25^{\circ} \mathrm{C}$ & Buoyant weight & Ferrier-Pagès et al., 2000 \\
\hline Pocillopora damicornis & Hawaii, North Pacific & $0.2-0.3$ & 3 months & In situ & $27^{\circ} \mathrm{C}$ & Buoyant weight & Piniak and Brown, 2008 \\
\hline
\end{tabular}


may not have influenced the long-term in situ skeletal growth rates on a micro scale (Försterra et al., 2005), thus potentially leading to an underestimation of growth rates (Jantzen et al., 2013a). The possible colonization by bioeroding organisms also provides another potential explanation for the stagnation, or even decrease in skeletal mass in two of the experimental specimens. Though the $T$. endesa specimens in this study thrive under the comparatively harsh conditions of Comau Fjord, the exponentially growing economic interest in the fjord region increases anthropogenic pressure. The input of nutrients, sediment due to mariculture and road construction, and the input of pharmaceutical and anti-fouling substances (introduced by the salmon-farming industry) is already a severe threat to vulnerable benthic communities of the Patagonian fjord region (Bustamante, 2009; Försterra et al., 2014, 2016).

\section{CONCLUSION}

This study reports on the skeletal growth rates of the CWC T. endesa, inhabiting the Patagonian fjord region, providing one of the first assessments of in situ growth of a solitary CWC species. While T. endesa specimens in Comau Fjord are exposed to environmental conditions (in particular with respect to the carbonate chemistry of the surrounding seawater) that can be considered unfavorable for calcification, this species displays skeletal growth rates comparable to other scleractinian coral species from less corrosive cold-water and temperate environments, such as L. pertusa and D. cornigera from the North Atlanic and the Mediterranean.

However, it remains unclear whether $T$. endesa will also be able to sustain and adapt to future environmental conditions, as benthic communities of the Chilean fjord region may be further threatened by proceeding climate change, including ocean acidification. In addition there is an increase in direct anthropogenic pressure from expanding fisheries, land use and road building (Häussermann and Försterra, 2007; Buschmann et al., 2009; Försterra et al., 2016). Although Patagonia represents one of the most important fjord systems in the subpolar margin, only little is known about local benthic communities and the physiological and ecological responses of these systems to regional oceanographic conditions (Pantoja et al., 2011). It is therefore indispensable to continue investigations on ecological processes and dependencies of this unique biocenosis. This will promote the endeavors for legal protection of CWC habitats (Häussermann and Försterra, 2007), as the highly diverse communities of this region may otherwise be irretrievably lost before even been investigated (Häussermann and Försterra, 2009).

\section{REFERENCES}

Addamo, A. M., Zaccara, S., Försterra, G., Höfer, J., García-Jiménez, R., Crosa, G., et al. (2021). Genetic conservation management of marine resources and ecosystems of patagonian fjords. Front. Mar. Sci. 8:96. doi: 10.3389/fmars.2021. 612195

\section{DATA AVAILABILITY STATEMENT}

The datasets presented in this study can be found in online repositories. The names of the repository/repositories and accession number(s) can be found below: PANGEA: https: //doi.org/10.1594/PANGAEA.846927, https://doi.org/10.1594/ PANGAEA.846928, and https://doi.org/10.1594/PANGAEA. 832187.

\section{AUTHOR CONTRIBUTIONS}

JL, VH, GF, and SR designed the experiment and contributed reagents, tools, and materials. SR, FR, and JL conducted the measurements. SR and FR analyzed the data, ran the formal analyses, and prepared the first draft. All authors contributed to improving the manuscript, read and approved the final manuscript.

\section{FUNDING}

This study was supported by BMBF (grant-01DN13029) and the Alfred-Wegener-Institut Helmholtz-Zentrum für Polar- und Meeresforschung (PACES II and the programme "Changing Earth-Sustaining our Future," Topic 4.2 and 6.1).

\section{ACKNOWLEDGMENTS}

We thank Erik Wurz, Henry Göhlich, Christopher Brunner, Svantje Gottschlich, and Maximilian (Max) Neffgen for their support with the field experiment, as well as the team of the Huinay Scientific Field Station, especially Ulrich (Ulo) Pörschmann and Kaitlyn (Katie) McConnell for their field support. We also acknowledge the support by the Open Access Publication Funds of Alfred-Wegener-Institut Helmholtz-Zentrum für Polar- und Meeresforschung.

\section{SUPPLEMENTARY MATERIAL}

The Supplementary Material for this article can be found online at: https://www.frontiersin.org/articles/10.3389/fmars. 2021.757702/full\#supplementary-material

Supplementary Table 1 | Buoyant weight data of the corals used in this study, and calculated growth (see also Fromula 2 in the main text).

Allemand, D., Tambutté, É, Zoccola, D., and Tambutté, S. (2011). "Coral calcification, cells to reefs," in Coral Reefs: An Ecosystem in Transition, eds Z. Dubinsky and N. Stambler (Dordrecht: Springer), doi: 10.1007/978-94-0070114-4_9

Bialek, E. L. (1966). Handbook of Oceanographic Tables. Washington, DC: U.S. Naval Oceanographic Office, 427. 
Brooke, S., and Young, C. M. (2009). In situ measurement of survival and growth of Lophelia pertusa in the northern Gulf of Mexico. Mar. Ecol. Prog. Ser. 397, 153-161. doi: 10.3354/meps 08344

Büscher, J., Form, A. U., and Riebesell, U. (2017). Interactive effects of ocean acidification and warming on growth, fitness and survival of the cold-water coral Lophelia pertusa under different food availabilities. Front. Mar. Sci. 4:101. doi: 10.3389/fmars.2017. 00101

Büscher, J., Wisshak, M., Form, A. U., Titschack, J., Nachtigall, K., and Riebesell, U. (2019). In situ growth and bioerosion rates of Lophelia pertusa in a Norwegian fjord and open shelf cold-water coral habitat. PeerJ 7:e7586.

Buschmann, A. H., Cabello, F., Young, K., Carvajal, J., Varela, D. A., and Henríquez, L. (2009). Salmon aquaculture and coastal ecosystem health in Chile: analysis of regulations, environmental impacts and bioremediation systems. Ocean Coast. Manag. 52, 243-249. doi: 10.1016/j.ocecoaman.2009.03. 002

Bustamante, M. S. (2009). The Southern Chilean Fjord Region: Oceanographic Aspects. Marine Benthic Fauna of Chilean Patagonia. Santiago: Nature In Focus, 53-60.

Cairns, S. (2007). Deep-water corals: an overview with special reference to diversity and distribution of deep-water scleractinian corals. Bull. Mar. Sci. 81, 311-322.

Cairns, S. D., Häussermann, V., and Försterra, G. (2005). A review of the Scleractinia (Cnidaria: Anthozoa) of Chile, with the description of two new species. Zootaxa 1018, 15-46.

Caldeira, K., and Wickett, M. E. (2003). Anthropogenic carbon and ocean pH. Nature 425, 365. doi: 10.1038/425365a

Carricart-Ganivet, J. P. (2004). Sea surface temperature and the growth of the West Atlantic reef-building coral Montastraea annularis. J. Exp. Mar. Biol. Ecol. 302, 249-260.

Castro, L. R., Cáceres, M. A., Silva, N., Muñoz, M. I., León, R., Landaeta, M. F., et al. (2011). Short-term variations in mesozooplankton, ichthyoplankton, and nutrients associated with semi-diurnal tides in a Patagonian Gulf. Cont. Shelf Res. 31, 282-292. doi: 10.1016/j.csr.2010.09.005

Chan, N. C. S., and Connolly, S. R. (2013). Sensitivity of coral calcification to ocean acidification: a meta-analysis. Glob. Chang. Biol. 19, 282-290. doi: 10.1111/gcb. 12011

Cohen, S., Krueger, T., and Fine, M. (2017). Measuring coral calcification under ocean acidification: methodological considerations for the ${ }^{45} \mathrm{Ca}$-uptake and total alkalinity anomaly technique. PeerJ 5:e3749. doi: 10.7717/peerj.3749

Comeau, S., Carpenter, R. C., and Edmunds, P. J. (2014). Effects of irradiance on the response of the coral Acropora pulchra and the calcifying alga Hydrolithon reinboldii to temperature elevation and ocean acidification. J. Exp. Mar. Biol. Ecol. 453, 28-35. doi: 10.1016/j.jembe.2013.12.013

Comeau, S., Gorsky, G., Jeffree, R., Teyssié, J.-L., and Gattuso, J.-P. (2009). Impact of ocean acidification on a key Arctic pelagic mollusc (Limacina helicina). Biogeosciences 6, 1877-1882.

Cyronak, T., Schulz, K. G., and Jokiel, P. L. (2016). The Omega myth: what really drives lower calcification rates in an acidifying ocean. ICES J. Mar. Sci. 73, 558-562. doi: 10.1093/icesjms/fsv075

Davies, P. S. (1989). Short-term growth measurements of corals using an accurate buoyant weighing technique. Mar. Biol. 101, 389-395. doi: 10.1016/j.jembe. 2011.06.022

Dickson, A. G., and Goyet, C. (1994). Handbook of Methods for the Analysis of the Various Parameters of the Carbon Dioxide System in Sea Water. Version 2. Oak Ridge, TN: Oak Ridge National Lab.

Diercks, S., Laudien, J., Roßbach, F., Häussermann, V., and Försterra, G. (2015a). Total Alkalinity Measured at Time Series Station Lilliguapi, Patagonia Chile, ed. Alfred Wegener Institute (Bremerhaven: PANGEA Repository). doi: 10.1594/PANGAEA.846927

Diercks, S., Laudien, J., Roßbach, F., Häussermann, V., and Försterra, G. (2015b). Total Alkalinity Measured at Time Series Station X-Huinay North, Patagonia Chile, ed. Alfred Wegener Institute (Bremerhaven: PANGEA Repository). doi: 101594/PANGAEA846928

Fabry, V. J., Seibel, B. A., Feely, R. A., and Orr, J. C. (2008). Impacts of ocean acidification on marine fauna and ecosystem processes. ICES J. Mar. Sci. 65, $414-432$.
Falkowski, P. G., Dubinsky, Z., Muscatine, L., and Porter, J. W. (1984). Light and the Bioenergetics of a Symbiotic Coral. BioScience 34, 705-709. doi: 10.2307/ 1309663

Feely, R. A., Byrne, R. H., Acker, J. G., Betzer, P. R., Chen, C.-T. A., Gendron, J. F., et al. (1988). Winter-summer variations of calcite and aragonite saturation in the northeast Pacific. Mar. Chem. 25, 227-241. doi: 10.1016/0304-4203(88) 90052-7

Feely, R. A., Sabine, C. L., Hernandez-Ayon, J. M., Ianson, D., and Hales, B. (2008). Evidence for upwelling of corrosive "Acidified" water onto the continental shelf. Sci. 320, 1490. doi: 10.1126/science.1155676

Ferrier-Pagès, C., Gattuso, J.-P., Dallot, S., and Jaubert, J. (2000). Effect of nutrient enrichment on growth and photosynthesis of the zooxanthellate coral Stylophora pistillata. Coral Reefs 19, 103-113.

Fillinger, L., and Richter, C. (2013). Vertical and horizontal distribution of Desmophyllum dianthus in Comau Fjord, Chile: a cold-water coral thriving at low pH. PeerJ 1:e194. doi: 10.7717/peerj.194

Flögel, S., Dullo, W.-C., Pfannkuche, O., Kiriakoulakis, K., and Rüggeberg, A. (2014). Geochemical and physical constraints for the occurrence of living cold-water corals. Deep Sea Res. Part II Top. Stud. Oceanogr. 99, $19-26$.

Form, A. U., and Riebesell, U. (2012). Acclimation to ocean acidification during long-term $\mathrm{CO}_{2}$ exposure in the cold-water coral Lophelia pertusa. Glob. Chang. Biol. 18, 843-853. doi: 10.1111/j.1365-2486.2011.02583.x

Försterra, G. and Häussermann, V. (2003): First report on large scleractinian (Cnidaria: Anthozoa) accumulations in cold-temperate shallow water of south Chilean fjords. Zoologische Verhandelingen Leiden 345, 117-128

Försterra, G., Beuck, L., Häussermann, V., and Freiwald, A. (2005). "Shallowwater Desmophyllum dianthus (Scleractinia) from Chile: characteristics of the biocoenoses, the bioeroding community, heterotrophic interactions and (paleo)-bathymetric implications," in Cold-Water Corals and Ecosystems, eds A. Freiwald and J. M. Roberts (Berlin: Springer), 937-977.

Försterra, G., Häussermann, V., and Laudien, J. (2016). "Animal forests in the chilean fjords: discoveries, perspectives, and threats in shallow and deep waters," in Marine Animal Forests, eds S. Rossi, L. Bramanti, A. Gori, and C. Orejas (Cham: Springer).

Försterra, G., Häussermann, V., and Lüter, C. (2008). Mass occurrence of the recent brachiopod Magellania venosa (Terebratellidae) in the fjords Comau and Renihue, northern Patagonia, Chile. Mar. Ecol. 29, 342-347.

Försterra, G., Häussermann, V., Laudien, J., Jantzen, C., Sellanes, J., and Muñoz, P. (2014). Mass die-off of the cold-water coral Desmophyllum dianthus in the Chilean Patagonian fjord region. Bull. Mar. Sci. 90, 895-899. doi: 10.5343/bms. 2013.1064

Freiwald, A., Fossa, J. H., Grehan, A., Koslow, T., and Roberts, J. M. (2004). Cold-Water Coral Reefs: Out of Sight-No Longer Out of Mind. Cambridge: UNEP-WCMC, 86.

Freiwald, A., Rogers, A., Hall-Spencer, J., Guinotte, J. M., Davies, A. J., Yesson, C., et al. (2021). Global Distribution of Cold-Water Corals (version 5.1). Fifth Update to the Dataset in Freiwald et al. (2004) by UNEP-WCMC, in Collaboration with Andre Freiwald and John Guinotte. Cambridge: UN Environment Programme World Conservation Monitoring Centre. doi: 10.34892/72x9-rt61

Gattuso, J.-P., Frankignoulle, M., Bourge, I., Romaine, S., and Buddemeier, R. W. (1998). Effect of calcium carbonate saturation of seawater on coral calcification. Glob. Planet. Chang. 18, 37-46. doi: 10.1016/s0921-8181(98)00035-6

Gran, G. (1952). Determination of the equivalence point in potentiometric titrations. Part II. Analyst 77, 661-671. doi: 10.1007/BF02332951

Grigg, R. W. (1974). Growth rings: annual periodicity in two gorgonian corals. Ecology 55, 876-881.

Guinotte, J. M., Orr, J., Cairns, S., Freiwald, A., Morgan, L., and George, R. (2006). Will human-induced changes in seawater chemistry alter the distribution of deep-sea scleractinian corals? Front. Ecol. Environ. 4:141-146. doi: 10.1890/ 1540-9295(2006)004[0141:whcisc]2.0.co;2

Hassenrück, C., Jantzen, C., Försterra, G., Häussermann, V., and Willenz, P. (2013). Rates of apical septal extension of Desmophyllum dianthus: effect of association with endolithic photo-autotrophs. Mar. Biol. 160, 2919-2927. doi: 10.1007/ s00227-013-2281-x

Häussermann, V., Föersterra, G., and Plotnek, E. (2012). Sightings of marine mammals and birds in the Comau Fjord, Northern Patagonia, between 2003 and mid 2012. Spixiana 35, 247-262. 
Häussermann, V., and Försterra, G. (2007). Large assemblages of cold-water corals in Chile: a summary of recent findings and potential impacts. Bull. Mar. Sci. 81, 195-207.

Häussermann, V., and Försterra, G. (eds) (2009). Marine Benthic Fauna of Chilean Patagonia. Puerto Montt: Nature in Focus, 1000.

Hennige, S. J., Wicks, L. C., Kamenos, N. A., Bakker, D. C. E., Findlay, H. S., Dumousseaud, C., et al. (2014). Short-term metabolic and growth responses of the cold-water coral Lophelia pertusa to ocean acidification. Deep Sea Res. Part II Top. Stud. Oceanogr. 99, 27-35.

Höfer, J., González, H. E., Laudien, J., Schmidt, G. M., Häussermann, V., and Richter, C. (2018). All you can eat: the functional response of the cold-water coral Desmophyllum dianthus feeding on krill and copepods. PeerJ 6:e5872. doi: $10.7717 /$ peerj. 5872

Houlbrèque, F., Tambutté, E., and Ferrier-Pagès, C. (2003). Effect of zooplankton availability on the rates of photosynthesis, and tissue and skeletal growth in the scleractinian coral Stylophora pistillata. J. Exp. Mar. Biol. Ecol. 296, 145-166.

Houlbrèque, F., Tambutté, E., Allemand, D., and Ferrier-Pagés, C. (2004). Interactions between zooplankton feeding, photosynthesis and skeletal growth in the scleractinian coral Stylophora pistillata. J. Exp. Biol. 207, 1461-1469. doi: $10.1242 /$ jeb.00911

Jaap, W. C. (2000). Coral reef restoration. Ecol. Eng. 15, 345-364.

Jantzen, C., Häussermann, V., Försterra, G., Laudien, J., Ardelan, M., Maier, S., et al. (2013a). Occurrence of a cold-water coral along natural pH gradients (Patagonia, Chile). Mar. Biol. 160, 2597-2607.

Jantzen, C., Laudien, J., Sokol, S., Försterra, G., Häussermann, V., Kupprat, F., et al. (2013b). In situ short-term growth rates of a cold-water coral. Mar. Freshw. Res. 64, 631-641.

Jokiel, P. (1978). Coral Reefs: Research Methods. Coral Growth: Buoyant Weight Technique. Paris: UNESCO, 529-541.

Jury, C. P., Whitehead, R. F., and Szmant, A. M. (2010). Effects of variations in carbonate chemistry on the calcification rates of Madracis auretenra (= Madracis mirabilis sensu Wells, 1973): bicarbonate concentrations best predict calcification rates. Glob. Chang. Biol. 16, 1632-1644. doi: 10.1111/j.1365-2486. 2009.02057.x

Kleypas, J. A., Mcmanus, J. W., and Menez, L. A. B. (1999). Environmental limits to coral reef development: where do we draw the line? Am. Zool. 39, 146-159. doi: 10.1093/icb/39.1.146

Larcom, E. A., McKean, D. L., Brooks, J. M., and Fisher, C. R. (2014). Growth rates, densities, and distribution of Lophelia pertusa on artificial structures in the Gulf of Mexico. Deep Sea Res. Part I Oceanogr. Res. Pap. 85, 101-109. doi: 10.1016/j.dsr.2013.12.005

Lartaud, F., Mouchi, V., Chapron, L., Meistertzheim, A.-L., and Le Bris, N. (2019). "Growth patterns of mediterranean calcifying cold-water corals," in Mediterranean Cold-Water Corals: Past, Present and Future, eds C. Orejas and C. Jiménez (Cham: Springer), 405-422. doi: 10.1007/978-3-319-91608-8_36

Lartaud, F., Pareige, S., de Rafelis, M., Feuillassier, L., Bideau, M., Peru, E., et al. (2014). Temporal changes in the growth of two Mediterranean cold-water coral species, in situ and in aquaria. Deep Sea Res. Part II Top. Stud. Oceanogr. 99, 64-70. doi: 10.1016/j.dsr2.2013.06.024

Laudien, J., Häussermann, V., Försterra, G., and Göhlich, H. (2014). Physical Oceanographic Profiles Of Seven CTD Casts From Gulf of Ancud into Comau Fjord in 2014. Alfred Wegener Institute, Helmholtz Centre for Polar and Marine Research. Bremerhaven: PANGAEA, doi: 10.1594/PANGAEA.832187

Lavigne, H., and Gattuso, J. (2013). in Package "seacarb": Seawater Carbonate Chemistry with $R$, ed. R Development Core Team. Available online at: https: //cran.r-project.org/web/packages/seacarb/index.html (accessed November 1, 2020).

Lueker, T. J., Dickson, A. G., and Keeling, C. D. (2000). Ocean $\mathrm{pCO}_{2}$ calculated from dissolved inorganic carbon, alkalinity, and equations for $\mathrm{K} 1$ and $\mathrm{K} 2$ : validation based on laboratory measurements of $\mathrm{CO}_{2}$ in gas and seawater at equilibrium. Mar. Chem. 70, 105-119.

Lüthi, D., Le Floch, M., Bereiter, B., Blunier, T., Barnola, J.-M., Siegenthaler, U., et al. (2008). High-resolution carbon dioxide concentration record 650,000800,000 years before present. Nature 453, 379-382. doi: 10.1038/nature06949

Maier, C., Schubert, A., Berzunza Sànchez, M. M., Weinbauer, M. G., Watremez, P., and Gattuso, J.-P. (2013). End of the century $\mathrm{pCO}_{2}$ levels do not impact calcification in Mediterranean Cold-Water Corals. PLoS One 8:e62655. doi: 10.1371/journal.pone.0062655
Martínez-Dios, A., Pelejero, C., López-Sanz, A., Sherrell, R., Ko, S., Häussermann, V., et al. (2020). Effects of low $\mathrm{pH}$ and feeding on calcification rates of the cold-water coral Desmophyllum dianthus. PeerJ 8:e8236. doi: 10.7717/peerj. 8236

Marubini, F., Barnett, H., Langdon, C., and Atkinson, M. J. (2001). Dependence of calcification on light and carbonate ion concentration for the hermatypic coral Porites compressa. Mar. Ecol. Prog. Ser. 220, 153-162. doi: 10.3354/meps220153

Marubini, F., Ferrier-Pagès, C., Furla, P., and Allemand, D. (2008). Coral calcification responds to seawater acidification: a working hypothesis towards a physiological mechanism. Coral Reefs 27, 491-499.

Matsumoto, A. K. (2007). Effects of low water temperature on growth and magnesium carbonate concentrations in the cold-water gorgonian Primnoa pacifica. Bull. Mar. Sci. 81, 423-435.

McCulloch, M., Falter, J., Trotter, J., and Montagna, P. (2012a). Coral resilience to ocean acidification and global warming through $\mathrm{pH}$ up-regulation. Nat. Clim. Chang. 2, 623-627. doi: 10.1038/srep42405

McCulloch, M., Trotter, J., Montagna, P., Falter, J., Dunbar, R., Freiwald, A., et al. (2012b). Resilience of cold-water scleractinian corals to ocean acidification: Boron isotopic systematics of $\mathrm{pH}$ and saturation state up-regulation. Geochim. Cosmochim. Acta 87, 21-34.

Mikkelsen, N., Erlenkeuser, H., Killingley, J. S., and Berger, W. H. (1982). Norwegian corals: radiocarbon and stable isotopes in Lophelia pertusa. Boreas $11,163-171$.

Montero, P., Daneri, G., Gonzalez, H. E., Iriarte, J. L., Tapia, F. J., Lizarraga, L., et al. (2011). Seasonal variability of primary production in a fjord ecosystem of the Chilean Patagonia: implications for the transfer of carbon within pelagic food webs. Cont. Shelf Res. 31, 202-215.

Mortensen, P. B., Rapp, H. T., and Båmstedt, U. (1998). Oxygen and carbon isotope ratios related to growth line patterns in skeletons of Lophelia pertusa (L) (Anthozoa, Scleractinia): Implications for determination of linear extension rate. Sarsia $83,433-446$.

Muñoz, P., Sellanes, J., Villalobos, K., Zapata-Hernandez, G., Mayr, C., and Araya Flores, K. (2014). Geochemistry of reduced fluids from shallow cold vents hosting chemosynthetic communities (Comau Fjord, Chilean Patagonia, $\sim 42^{\circ}$ S). Prog. Oceanogr. 129, 159-169. doi: 10.1016/j.pocean.2014.10.003

Naumann, M. S., Orejas, C., Wild, C., and Ferrier-Pagès, C. (2011). First evidence for zooplankton feeding sustaining key physiological processes in a scleractinian cold-water coral. J. Exp. Biol. 214, 3570-3576. doi: 10.1242/jeb. 061390

Orejas, C., Ferrier-Pagès, C., Reynaud, S., Gori, A., Béraud, E., Tsounis, G., et al. (2011). Long-term growth rates of four Mediterranean cold-water coral species maintained in aquaria. Mar. Ecol. Prog. Ser. 429, 57-65. doi: 10.3354/meps09104

Orr, J. C., Fabry, V. J., Aumont, O., Bopp, L., Doney, S. C., Feely, R. A., et al. (2005). Anthropogenic ocean acidification over the twenty-first century and its impact on calcifying organisms. Nature 437, 681-686. doi: 10.1038/nature04095

Palma, S., and Silva, N. (2004). Distribution of siphonophores, chaetognaths, euphausiids and oceanographic conditions in the fjords and channels of southern Chile. Deep Sea Res. Part II Top. Stud. Oceanogr. 51, 513-535.

Pantoja, S., Iriarte, J., and Daneri, G. (2011). Oceanography of the Chilean Patagonia. Cont. Shelf Res. 31, 149-153. doi: 10.1016/j.csr.2010.10.013

Pickard, G. L. (1971). Some physical oceanographic features of inlets of Chile. J. Fish. Res. Board Can. 28, 1077Ü1106. doi: 10.1139/f71-163

Piniak, G. A., and Brown, E. K. (2008). Growth and mortality of coral transplants (Pocillopora damicornis) along a range of sediment influence in Maui, Hawai' i. Pacif. Sci. 62, 39-55. doi: 10.2984/1534-6188(2008)62[39:gamoct]2.0.co;2

Purser, A., Larsson, A. I., Thomsen, L., and van Oevelen, D. (2010). The influence of flow velocity and food concentration on Lophelia pertusa (Scleractinia) zooplankton capture rates. J. Exp. Mar. Biol. Ecol. 395, 55-62. doi: 10.1016/j. jembe.2010.08.013

Rinkevich, B. (2014). Rebuilding coral reefs: does active reef restoration lead to sustainable reef restoration lead to sustainable reefs? Curr. Opin. Environ. Sustain. 7, 28-36. doi: 10.1016/j.cosust.2013.11.018

Roberts, J., Wheeler, A., Freiwald, A., and Cairns, S. (2009). Cold Water Corals: The Biology and Geology of Deep-Sea Coral Habitats. Cambridge: Cambridge University Press, 1-350.

Roberts, J. M., Wheeler, A. J., and Freiwald, A. (2006). Reefs of the deep: the biology and geology of cold-water coral ecosystems. Science 312:543. doi: 10. $1126 /$ science. 1119861 
Rodolfo-Metalpa, R., Peirano, A., Houlbrèque, F., Abbate, M., and Ferrier-Pagès, C. (2008). Effects of temperature, light and heterotrophy on the growth rate and budding of the temperate coral Cladocora caespitosa. Coral Reefs 27, 17-25. doi: 10.1007/s00338-007-0283-1

Rojas, N., and Silva, N. (2005). Early diagenesis and vertical distribution of organic carbon and total nitrogen in recent sediments from southern Chilean fjords (Boca del Guafo to Pulluche Channel). Investig. Mar. 33, 183-194.

Rossin, A. M., Waller, R. G., and Försterra, G. (2017). Reproduction of the cold-water coral Primnoella chilensis (Philippi, 1894). Cont. Shelf Res. 144, 31-37.

Sánchez, N., González, H. E., and Iriarte, J. L. (2011). Trophic interactions of pelagic crustaceans in Comau Fjord (Chile): their role in the food web structure. J. Plankton Res. 33, 1212-1229. doi: 10.1093/plankt/fbr022

Schutter, M., van der Ven, R. M., Janse, M., Verreth, J. A. J., Wijffels, R. H., and Osinga, R. (2012). Light intensity, photoperiod duration, daily light flux and coral growth of Galaxea fascicularis in an aquarium setting: a matter of photons? J. Mar. Biol. Assoc. U.K. 92, 703-712.

Schwabe, E., Försterra, G., Häussermann, V., Melzer, R., and Schroedl, M. (2006). Chitons (mollusca: polyplacophora) from the southern chilean comau fjord, with reinstatement of tonicia calbucensis plate, 1897. Zootaxa $1341,1-27$.

Silva, N. (2008). "Dissolved oxygen, pH, and nutrients in the austral chilean channels and fjords," in Progress in the Oceanographic Knowledge of Chilean Interior Waters, Puerto Montt to Cape Horn, eds $\mathrm{N}$. Silva and S. Palma (Valparaíso: Pontificia Universidad Católica de Valparaíso), 37.

Silverman, J., Lazar, B., and Erez, J. (2007). Effect of aragonite saturation, temperature, and nutrients on the community calcification rate of a coral reef. J. Geophys. Res. 112:C05004.

Tanaka, Y., Miyajima, T., Koike, I., Hayashibara, T., and Ogawa, H. (2007). Imbalanced coral growth between organic tissue and carbonate skeleton caused by nutrient enrichment. Limnol. Oceanogr. 52, 1139-1146.
Valle-Levinson, A., Sarkar, N., Sanay, R., Soto, D., and León, J. (2007). Spatial structure of hydrography and flow in a Chilean fjord, Estuario Reloncaví. Estuar. Coasts 30, 113-126.

Wall, M., Schmidt, G. M., Richter, C., and de Beer, D. (2016). Regulation of Internal $\mathrm{pH}$ by the Coldwater Coral Desmophyllum dianthus. Washington, DC: American Geophysical Union.

Wolf-Gladrow, D. A., Zeebe, R. E., Klaas, C., Körtzinger, A., and Dickson, A. G. (2007). Total alkalinity: the explicit conservative expression and its application to biogeochemical processes. Mar. Chem. 106, 287-300. doi: 10. 1016/j.marchem.2007.01.006

Zeebe, R. E., and Wolf-Gladrow, D. (2001). $\mathrm{Co}_{2}$ in Seawater: Equilibrium, Kinetics, Isotopes. New York, NY: Gulf Professional Publishing, 65.

Zheng, M.-D., and Cao, L. (2014). Simulation of global ocean acidification and chemical habitats of shallow- and cold-water coral reefs. Adv. Clim. Chang. Res. 5, 189-196. doi: 10.1016/j.accre.2015.05.002

Conflict of Interest: The authors declare that the research was conducted in the absence of any commercial or financial relationships that could be construed as a potential conflict of interest.

Publisher's Note: All claims expressed in this article are solely those of the authors and do not necessarily represent those of their affiliated organizations, or those of the publisher, the editors and the reviewers. Any product that may be evaluated in this article, or claim that may be made by its manufacturer, is not guaranteed or endorsed by the publisher.

Copyright (c) 2021 Rossbach, Rossbach, Häussermann, Försterra and Laudien. This is an open-access article distributed under the terms of the Creative Commons Attribution License (CC BY). The use, distribution or reproduction in other forums is permitted, provided the original author(s) and the copyright owner(s) are credited and that the original publication in this journal is cited, in accordance with accepted academic practice. No use, distribution or reproduction is permitted which does not comply with these terms. 